\title{
The relevance of international water law to later-developing upstream states
}

\author{
Mark Zeitoun* \\ Water Security Research Centre, School of International Development, University of East Anglia, \\ Norwich, UK
}

(Received 15 January 2015; accepted 26 September 2015)

\begin{abstract}
The relevance of the main instruments of international water law to the hydraulic development projects of later-developing upstream states is explored, for a non-legal audience. Relevance is gauged by querying common misperceptions, checking the compatibility of the instruments, and considering their effect along the Nile, Jordan and Tigris Rivers and associated aquifers. Specific principles of international water law are found to support upstream development in theory, though its relevance is threatened by incompatibility of clauses between the instruments, the erosion of normbuilding processes, and a shift away from the idea that territorial sovereignty over a fluid resource should be limited.
\end{abstract}

Keywords: international water law; water politics; UN Watercourses Convention; Draft Aquifer Articles; Nile; Jordan; Tigris

\section{Introduction}

Support for international water law (IWL) is gaining momentum. The last few years has witnessed the opening of the UNECE's Water Convention beyond Europe (in 2011), ${ }^{1}$ the entry into force of the UN Watercourses Convention (in 2014), and a lively ongoing debate at the UN General Assembly over the Draft Articles on the Law of Transboundary Aquifers (Draft Aquifer Articles). These follow the General Assembly's recognition of the Human Right to Water in 2010, and renewed interest in the water aspects of international criminal law and international humanitarian law. ${ }^{2}$ The question arises in the non-legal water community: Should we care enough about this progress to learn the language and issues, and engage in the debates?

Certainly water resource managers, diplomats and researchers should, for tensions between upstream and downstream states are increasing, and a compelling case has been made that IWL favours those downstream nations that have already developed the transboundary resource (Wegerich \& Olsson, 2010). This article queries that argument by investigating the extent to which IWL is relevant to the later-developing, upstream states. It follows a tradition of articles on water law in Water International (e.g. Leb, 2015; Vink, 2014; Wouters \& Chen, 2015), though in considering also the politics of water interaction between states, it is written for a non-legal water audience. The relevance is gauged by reviewing common misperceptions about law and lesser-known clauses, then by cross-checking the mutual compatibility of the many legal instruments that make up the body of IWL, and finally by querying the effect of IWL on the behaviour

*Email: m.zeitoun@uea.ac.uk 
of riparian states along the Jordan, Nile, and Tigris Rivers and associated aquifers. This is preceded by a critical review of the relevant legal principles and debates, and followed by discussion of the implications of the findings.

The analysis finds that on the whole, IWL is entirely relevant to all late-developing upstream states. Taken (momentarily) out of the political context, the chief legal instruments are found to contain no provisions which compromise upstream development or privilege downstream development. This theoretical relevance of IWL is found to be threatened, however, through a perceptible shift away from coordinated to unilateral transboundary activity, through erosion of the norm-building feature of international law (as when IWL is ignored or discredited by those seeking to maintain the status quo) and through incompatible clauses (in particular the sovereignty clause in the Draft Aquifer Articles). IWL's actual influence over the transboundary water arrangements in the cases considered is found to be qualified, revealing how the threats may and do play out in practice. The article argues that the advances IWL has made in tackling the collective challenge of governing a fluid transboundary resource across static territorial borders may be reversed, suggesting that work to harmonize the interests gains even greater importance, and that the non-legal water community should have greater influence over the phenomena.

\section{Background: the development and politics of IWL}

Past and future challenges of IWL: reconciling watercourse boundaries and political borders

The mid-to-late twentieth century, during which IWL blossomed, was an era largely dominated by early-developing downstream nations, reflecting thousands of years of human settlement along the flat and fertile lower reaches of rivers. Successive Egyptian governments developed the Nile's irrigation and hydroelectric potential through the dams in Aswan in the early 1900s and 1960s, for example, several decades ahead of the recent upstream Ethiopian efforts. Likewise, downstream Iraqi development of the Tigris and Euphrates throughout the 1950s and 1970s preceded the ongoing irrigation and (relatively much larger) hydropower dams developed by Turkey from the 1990s onwards. And Israel's draining of the Huleh marshes, damming of the Lake of Tiberias, and extensive groundwater development from the 1950s to the 1970s was completed at least 50 years ahead of the dams and deep wells that the governments of Lebanon and Palestine still seek to build on a tributary of the Jordan River and transboundary aquifers. The 'hydraulic missions' of these downstream governments enabled a degree of control over their societies, and in many cases helped the states flourish economically (see e.g. Allan, 2001; Molle, Mollinga, \& Wester, 2009; Swyngedouw, 1999). But the states also became dependent on the use of the established flows, and so, vulnerable - indefinitely - to any upstream water development projects.

Currently, the upstream states are proceeding headlong in their own hydraulic missions, and, unlike the downstreamers, maintain sovereignty over the territory where the transboundary flows originate. Dams on the drawing board or under construction in Ethiopia, Lebanon, Turkey and Iran generate concern regarding their downstream impact that downstreamers were never obliged to contemplate - and set up what Wouters (2014, p. 67) refers to as the "upstream dilemma". The response is often one of effective sabrerattling. Through a number of tactics and strategies, downstream Egypt, Israel and Iraq have managed to thwart the intended upstream development - at least for as long as asymmetries in power have favoured them (Salman, 2013; Zawahri, 2008; Zeitoun et al., forthcoming). 
Transboundary water management, diplomacy and law thus have their work cut out. IWL in particular is intended "to determine a State's entitlement to the benefits of the watercourse ... and to establish certain requirements for States' behaviour while developing the resource" (Wouters, Vinogradov, Allan, Jones, \& Rieu-Clarke, 2005, p. 15). In other words, IWL is meant to establish a state's rights and obligations vis-à-vis other states with respect to transboundary water. Unlike national law, there can be no direct enforcement of IWL, but it can build norms about 'acceptable' state behaviour and guide bilateral or multilateral treaties (to which IWL is always subordinate).

IWL is thus at the heart of a broader and very current debate about how sovereign political entities may jointly govern, or at least coordinate, the development of common resources in a sustainable manner (see e.g. Eckersley, 2004; Litfin, 1997). The international borders that water flows across, underneath, or above (in rivers, aquifers, or clouds) set up particular "hydropolitical constellations" (Hensengerth, Dombrowski, \& Scheumann, 2012) that water managers, analysts and diplomats should consider. In legal terms, the dissonance pits the new doctrine of limited territorial sovereignty against the old doctrine of absolute territorial sovereignty.

\section{From absolute to limited territorial sovereignty, and from no harm to equitable and reasonable use - and back again?}

Insofar as it is possible to do so in lay terms, this section recounts the evolution of IWL through its many different bodies and instruments. ${ }^{3}$ The interstate conflicts created by boundary-border dissonance and the uncoordinated development of rivers has been addressed by the international water legal community through the development of at least four doctrines and dozens of principles of interstate water sharing. The development of a selection of these is tracked in Figure 1, and discussed in the following. ${ }^{4,5}$

The doctrine of absolute territorial sovereignty asserts that a "state is free to dispose, within its territory, of the waters of an international river in any manner it deems fit" (Salman, 2007, p. 627). At a superficial level, this doctrine (also known as the Harmon Doctrine) seems clearly in the interests of upstream states, and has been largely discredited as a principle due to the serious impact it can allow upon downstream states (in the most extreme cases, all flows may be diverted or retained). In contrast, the doctrine of limited territorial sovereignty asserts that "every riparian State has a right to use the waters of the international river, but is under a corresponding duty to ensure that such use does not harm other riparians" (Salman, 2007, p. 627). In many senses, the doctrine of limited territorial sovereignty (also known as shared sovereignty - see McIntyre, 2007; Stephens, 2012) tackles basin-border dissonance by trying to rise above the restrictive notion of sovereignty, while absolute territorial sovereignty seeks to re-establish a centuries-old order. Both doctrines appear to be influential, currently.

Concern about downstream impact drove the development of the original principle of IWL in 1911: 'no harm'. Very much in the spirit of absolute territorial sovereignty, the principle of no harm means that the development of a resource by one state must not harm another state. The International Law Association (hereafter, the Association) may have been the first to challenge the doctrine of absolute territorial sovereignty, through its 1956 Dubrovnik Statement and 1958 New York Resolution. The basic right of states to a "reasonable and equitable share" of water was declared there for the first time internationally, and was later developed in the Helsinki Rules. The UN Economic Commission for Europe (UNECE) drew on the ILA's Helsinki Rules and the International Law Commission's (the Commission's) ongoing work, which calls for 


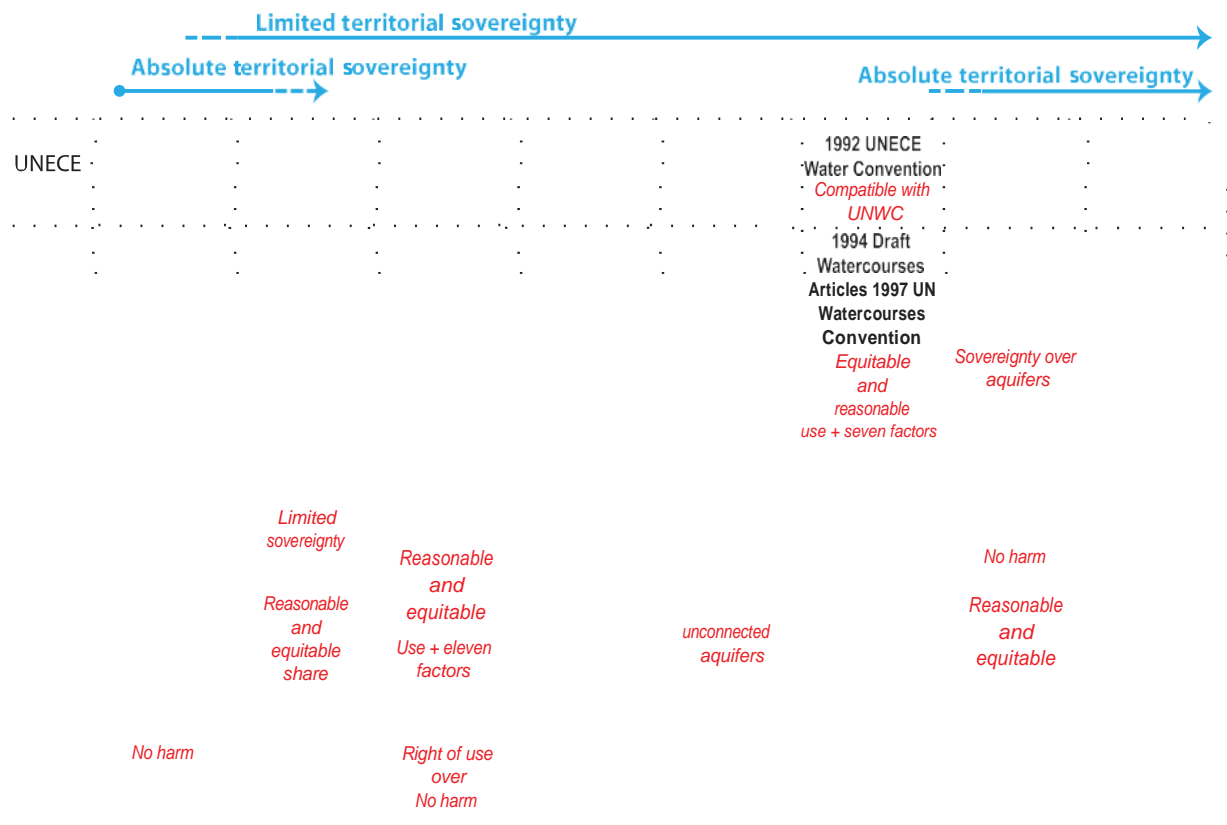

Figure 1. Developments in international water law, at times coevolving, at others evolving independently. The principles (in italics) are developed by different international bodies and form part of various instruments. The shifts in guiding doctrines are shown across the top of the figure. Based on Dellapenna (2003); McCaffrey (2007); Rieu-Clarke, Moynihan, \& Magsig (2012); Salman, (2007).

states parties "to ensure that transboundary waters are used in an equitable and reasonable way".

The Commission meanwhile completed its codification of state practice in 1994, leading to the adoption in 1997 of the UN Watercourses Convention (UNWC), which details obligations of "no significant harm", "prior notification", and "equitable and reasonable use". Drawing heavily on the Association's Helsinki Rules, the UNWC also details seven illustrative factors from which equitable and reasonable use may be derived (as discussed later). It entered into force with its 35th state ratification, in August 2014.

On the back of the development of the UNWC, the Association developed the Helsinki Rules into the 1999 Campione Consolidation and the 2004 Berlin Rules. The UNECE Water Convention entered into force in 1996 (UNECE, 1992, 2011), ${ }^{6}$ and was opened to ratification beyond Europe in 2012 (Tanzi, 2013). With the support of the UNESCO International Hydrological Programme, the Commission tabled the Draft Aquifer Articles in 2008. The Draft Aquifer Articles had initially set out to fill a perceived gap of the UNWC in relation to fossil water, but they have evolved to emphasize aquifers rather than groundwater itself, and are currently being discussed at the UN General Assembly. ${ }^{7}$

A debate reflecting the philosophical grounding of the main doctrines has developed from these many different instruments and processes, notably the primacy of equitable and reasonable use versus no significant harm (see e.g. Brooks, 2011; Dellapenna, 2001; McCaffrey, 2008; McIntyre, 2007; Wegerich \& Olsson, 2010). The case for the supremacy 
of equitable and reasonable use is based on the detail of its seven illustrative factors - which includes the possible harm (as well as benefits) of the intended use, as discussed later. The approach is pragmatic, in the sense that it accepts that all states, including late-developing upstream states, will in one way or another 'develop' their resources, and that some harm is inevitable (McCaffrey, 2007, chs. 10, 11) - consistent with the doctrine of limited territorial sovereignty, in other words, and a rejection of absolute territorial sovereignty.

With the development of the 2004 Berlin Rules and the 2008 Draft Aquifer Articles, the debate has been given a new twist. The Draft Aquifer Articles' most contentious passage is in Article 3, which states that "Each aquifer State has sovereignty over the portion of the transboundary aquifer or aquifer system located within its territory. It shall exercise its sovereignty in accordance with international law and the present draft articles" (emphasis added). The introduction of a role for state sovereignty suggests a return to the guiding doctrine of absolute territorial sovereignty and, indirectly, the supremacy of the no harm principle. Arguments in support of such an introduction are centred around the fact that the draft articles relate to the structure of the aquifer, not directly to the groundwater running through it (Del Castillo-Laborde, 2011; Eckstein, 2011), or improved political acceptability to UN member states (Eckstein \& Sindico, 2014). Arguments against the clause align with general concern about the re-assertion of state interests and positions, rather than common ones (McCaffrey, 2014; McIntyre, 2011). The debate is entered further into here only to the extent that it is relevant to the purposes of this article; that is, by noting that this introduction opens the door of law-making processes a little wider to the vagaries of realist international politics.

\section{Law: subject of politics, or norm building?}

If we accept that the politics and legal wrangling over transboundary waters are shaped by - and not determining of - the broader political context within which they play out (see e.g. Brunnée \& Toope, 2002; Rieu-Clarke, 2010), it follows that the relevance of IWL must be considered within the enabling or constraining effects of the international political setting within which it operates. There is no reason to believe that IWL should be spared the shortcomings that general international law is exposed to. These have been identified as the lack of central enforcement; the decentralized structure that favours strong over weak states; and the numerous violations which occur with impunity (see e.g. Hathaway, 2005; Koh, 1997).

IWL is downplayed or ignored on similar grounds, or for being subordinate to international treaties, for instance, in much water conflict resolution or hydro-diplomacy research (e.g. Delli-Priscoli \& Wolf, 2008; Trondalen, 2008; Cronin \& Hamlin, 2010; Stimson, 2010; DNI, 2012; and see discussion in Magsig, 2015).

The UNWC itself has been criticized for being too vague (Beaumont, 2005) or misleading (Lankford, 2013), and Moussa (2013) argues that application of the UNWC in the case of the Nile ended up "institutionalising conflict". The convention has also been blamed for replicating in new areas the neoliberal economic and political foundations upon which it was created (D'Souza, 2010). The line of argument is that law may be considered simply a tool to promote the interests of powerful states, for instance by facilitating treaties that are skewed in their favour (Zeitoun \& Warner, 2006).

As Wegerich and Olsson (2010) point out, the reasoning is consistent with a realist and critical-realist view of the political order of the world. Certainly, asymmetric use and control of flows abound (Dinar, Katz, De Stefano, \& Blankspoor, 2012; Gleditsch, Furlong, Hegre, Lacina, \& Owen, 2006), and in most hegemonic contexts very much 
reflects the balance of power between the riparian states (Fox \& Sneddon, 2007; Olmstead \& Sigman, 2014; Zeitoun, Mirumachi, \& Warner, 2011).

Theory seeking to explain when and why states do comply with international law argues that it serves national interests, either through its use as a rhetorical device or in the promotion of international norms (see e.g. Goldsmith \& Posner, 2005, § 3). IWL itself has been noted to influence the development of norms through "interest-shaping" (Koh, 1997, p. 2562) and norm-building processes (Brunnée \& Toope, 2002; see also Hathaway, 2005; Rieu-Clarke, 2010; Cullet, 2011; McCaffrey, 2013; Acharya, in Çonker, 2014). The use of IWL as a rhetorical device has also been noted as a way to increase bargaining power (Daoudy, 2008) and is definitely of relevance to the cases considered in what follows.

Testing the relevance of IWL to upstream states

While the political wrangling and legal debates rage, the concrete continues to pour into some large upstream water infrastructure projects. This section tests the relevance of IWL to such projects of upstream states, first by reviewing less well-known principles, thereby checking for gaps in IWL's theoretical coverage; then by cross-checking the mutual compatibility of the legal instruments, to verify coherence; and finally by querying its effect on the behaviour of riparian states along the Jordan, Nile, and Tigris Rivers and associated aquifers, to test the match of theory and reality.

\section{Rethinking perceptions of how principles and arguments support upstream or downstream states: foreclosure of future uses, countermeasures and reciprocity}

Many in the non-legal water community may hold perceptions about which principles of law favour up- or downstreamers. It is expected, for example, that developed downstream states (say, Egypt) will promote the principle of no harm in order to protect against upstream hydraulic development. Upstream states (e.g. Ethiopia) would be expected to push for equitable and reasonable use, as it provides some scope for use of the water at a later stage in their development trajectory (see e.g. McIntyre, 2015).

But IWL is much more nuanced. Perhaps counter-intuitively, the no harm obligation may actually support the development plans of upstream states, especially if the downstream state has extensively developed the watercourse in question. As McCaffrey (2007) and Salman (2010) point out, there is increasing recognition (reflected in practice ${ }^{8}$ ) that upstream use of the flows can be foreclosed when downstream development of a watercourse is so extensive that any action by the upstream state will cause downstream harm, or give rise to downstream claims of inequitable use. India's concerns with (then-downstream) Pakistani development on the Ganges, and Ethiopia's official reply to Egyptian development of the Toshka on the Nile, both reveal upstreamers' awareness that downstream development does not or should not compromise the right of the former to develop (Salman, 2010). Known as foreclosure of future uses, the logic ensures that development by downstream states is not favoured, at least on paper - and also leads to a related debate about whether existing or potential uses have priority (Wouters et al., 2005).

The legal measures of countermeasures and reciprocity may also challenge our assumptions. Countermeasures are "measures, which would otherwise be contrary to the international obligations of an injured State vis-à-vis the responsible State" (UN, 2012, p. 304) legitimate breaches of law, to use non-legal terms. The principle of countermeasures could thus be used to assert that a violation of an obligation under IWL by one state could lead to a legitimate proportional breach of a corresponding obligation by another state, so long as 
the initial violation consists of a 'serious or material' breach. As will be discussed, this means that upstream Ethiopia or Lebanon could be within its legal rights to proportionally breach the no harm obligation, if downstream Egypt or Israel had breached the obligation ensuring equitable and reasonable use in a 'serious and material' way. Proportionality is all but guaranteed, furthermore, where a countermeasure is taken by way of reciprocity. As noted in AFIAL (2014), this approach has been recognized by the International Court of Justice in the context of transboundary waters in the case of the Gabcikovo-Nagymaros Project (Hungary v. Slovakia). ${ }^{9}$

\section{Compatibility check of legal instruments}

From a norm-building perspective, the more that the legal principles and main instruments are aligned, the more robust is the body of law itself. The opposite holds true as well; incompatibility between the principles and instruments may ultimately weaken the body of law, because the great number of interpretations they allow can eventually discredit its reputation as an objective tool. The relevance of IWL to any state (whether up- or downstream, and early- or late-developing) is thus tied to the degree of harmony amongst the instruments. Table 1 assesses the compatibility of the more relevant principles found in some or all of the three main legal instruments, and these are discussed in what follows. ${ }^{10}$

\section{Equitable and reasonable utilization, and factors relevant to its determination}

The principle of equitable and reasonable use of transboundary waters is mentioned explicitly in the UNWC (Art. 5), the Draft Aquifer Articles (Art. 4), and the UNECE

Table 1. Mutual Compatibility check of the main principles of selected international water legal instruments.

\begin{tabular}{|c|c|c|c|c|c|}
\hline Obligations & $\begin{array}{c}\text { UN } \\
\text { Watercourses } \\
\text { Convention } \\
\text { (UNWC) }\end{array}$ & $\begin{array}{c}\text { UNECE } \\
\text { Water } \\
\text { Convention }\end{array}$ & $\begin{array}{l}\text { Draft Aquifer } \\
\text { Articles }\end{array}$ & $\begin{array}{c}\text { General remarks/ } \\
\text { observations/ } \\
\text { implications }\end{array}$ & Compatible? \\
\hline $\begin{array}{l}\text { Equitable and } \\
\text { reasonable } \\
\text { utilization } \\
\text { (ERU) }\end{array}$ & $\begin{array}{l}\text { Art. 5; also Art. } \\
\text { 24, pars A } \\
\text { and B }\end{array}$ & Art. 2-c & Art. 4 & $\begin{array}{l}\text { The UNWC also adds } \\
\text { "optimal and } \\
\text { sustainable } \\
\text { utilisation" }\end{array}$ & Yes \\
\hline $\begin{array}{l}\text { Factors relevant } \\
\text { to ERU }\end{array}$ & $\begin{array}{l}\text { Art. } 6 \text { (cf. Art. } \\
\text { 24, par. 2-b, } \\
\text { and Art. 8) }\end{array}$ & $\mathrm{n} / \mathrm{m}$ & Art.5 & $\begin{array}{l}\text { Art. 24, par. 2-b, of } \\
\text { UNWC adds } \\
\text { "rational } \\
\text { utilisation"; Art. } 8 \\
\text { adds "spirit of } \\
\text { cooperation" }\end{array}$ & Yes \\
\hline $\begin{array}{l}\text { Prevention of } \\
\text { significant } \\
\text { harm }\end{array}$ & Art. 7; Art. 32 & $\mathrm{n} / \mathrm{m}$ & Art. 6 & $\mathrm{n} / \mathrm{m}$ & Yes \\
\hline Prior notification & Art. 12 & $\mathrm{n} / \mathrm{m}$ & Art. 15.2 & $\mathrm{n} / \mathrm{m}$ & Yes \\
\hline Sovereignty & $\mathrm{n} / \mathrm{m}$ & $\mathrm{n} / \mathrm{m}$ & $\begin{array}{l}\text { Art. 3, Sovereignty } \\
\text { of aquifer states } \\
\text { (territorialism) }\end{array}$ & $\begin{array}{l}\text { See discussion } \\
\text { throughout text }\end{array}$ & No \\
\hline
\end{tabular}

Note: ' $\mathrm{n} / \mathrm{m}$ ' indicates that the concerned obligation/principle/rule is not mentioned in the specific legal instrument; 'Yes' indicates that the specified obligation/rule/principle is not incompatible between the international legal instruments; 'No' indicates incompatibility between some or all of the instruments. 
Water Convention (Art. 2-c). The UNWC (Art. 6 and Art. 24, par. 2-b) and the Draft Aquifer Articles (Art. 5) elaborate upon the factors relevant to its definition, with the most relevant differences discussed in what follows. Though these differences are not significant enough to represent incompatibility between the two legal instruments, they may well lead to support of considerably different positions in political processes, though in ways that are not discussed further here. Relevant factors include the following.

(1) Particular biophysical aspects of the body of water under consideration. As would be expected, the Draft Aquifer Articles refer much more clearly to aquifers and groundwater, specifying the quantification of "the contribution to the formation and recharge of the aquifer or aquifer system" (Article 5.1d). They also distinguish between the geological particularities or aquifers (i.e. their formation and recharge dynamics), though this latter point is comparable to the UNWC's "factors of a natural character".

(2) Use versus effect. The Draft Aquifer Articles are marked, too, by explicitly stating that both the "actual and potential effects" of the utilization of the aquifer or aquifer system are to be taken into consideration, whereas the UNWC limits its enumeration to "existing and potential uses". The wording of the Draft Aquifer Articles here might favour downstream states that have already developed their resources, for the stress is placed upon impact rather than use.

(3) Vital human needs. While "vital human needs" is mentioned explicitly in the UNECE Water Convention and the UNWC, the Draft Aquifer Articles go further in suggesting that "special regard" be given to them when determining equitable and reasonable use (Art. 5.2). This addition would seem to favour riparian states with communities that are more dependent on the resource (i.e. early-developing downstream states).

(4) Factors versus circumstances. The UNWC states that "all relevant factors and circumstances" must be taken into account when determining equitable and reasonable use; the Draft Aquifer Articles shorten this to "all relevant factors". This omission is not explained, and while suggesting reduction of space for the consideration of particular circumstances, it may be nothing more than a simplification of definition.

(5) Economy of use. Whereas the UNWC suggests consideration of "conservation, protection, development and economy of use", the Draft Aquifer Articles do not include the latter term. This could allow space in the UNWC for an argument favouring the riparian state that is more economically 'efficient' with their use of water - in terms of 'crops per drop' or 'dollars per drop' (Allan, 2001), for example.

(6) Comparable value of alternatives. The UNWC is the sole instrument which specifies that evaluation of available alternatives shall be "of comparable value". This means that a state should not be forced to use an alternative in order to avoid disadvantaging another state when that alternative is of significantly less value - and may be seen to be to the advantage of (wet) latedeveloping upstream states.

(7) Spirit of cooperation. The UNWC is also the only instrument which obliges states to "enter into consultations in a spirit of cooperation". Omission of this language from the Draft Aquifer Articles is not explained, but it can be hypothesized that the Commission considered it redundant in light of the "general obligation to cooperate" (Draft Art. 7). 


\section{Prevention of significant harm}

The obligation not to cause significant harm is stated explicitly in Articles 7 (and 32) of the UNWC and in Article 6 of the Draft Aquifer Articles. No incompatibility is generated by the omission of this obligation from the UNECE Water Convention, given the latter's overall tenor and raison d'être. ${ }^{11}$

\section{Prior notification}

According to the UNWC (Art. 12) and Draft Aquifer Articles (Art. 15.2), states intending any measures on a transboundary watercourse have an obligation to provide notification of a specified period to other states that may suffer from "the implementation of planned measures which may have a significant adverse effect upon other watercourse States" (to use the UNWC's wording). No such obligation exists in the UNECE Water Convention. The principle of foreclosure of future uses suggests a flip side to the obligation, however. If downstream development of a watercourse is so extensive that any action by the upstream state will cause downstream harm, or give rise to downstream claims of inequitability, it follows that the downstream state should also notify its upstream coriparian of contemplated projects affecting the watercourse.

\section{Sovereignty}

Considering the earlier discussion of how the introduction of 'sovereignty' into the body of IWL may indicate a shift away from the doctrine of limited territorial sovereignty towards that of absolute territorial sovereignty, it is not surprising to find it as the main incompatible element between the instruments considered here. Quite apart from the previously discussed advantages and disadvantages of the role of 'sovereignty', the incompatibility introduced between the two instruments weakens the body of law as a whole, in the normative sense. Should the Draft Aquifer Articles become an international convention, it is possible that states that do not ratify (or that do not openly support) the UNWC may end up supporting an aquifer convention, or vice versa. Such incompatibility may make IWL a tool for competition between different instruments, rather than for practical cooperation.

\section{IWL at use for upstream states on the Jordan, Nile and Tigris Rivers}

This section queries the potential and actual effect of IWL in support of the hydraulic development plans of the upstream riparians along the Eastern Nile, Jordan and Tigris Rivers. The cases are summarized in Table 2, and discussed in the following.

\section{Eastern Nile River}

Ethiopia's decision in 2010 to push ahead with the signature (and probably eventual ratification) of the NBI-initiated Cooperative Framework Agreement has been interpreted as a reflection of the change of power away from Egypt (Cascão, 2014; Nicol \& Cascão, 2011). Certainly it was a direct challenge to the 1959 Nile Agreement between (only) Egypt and Sudan. The Cooperative Framework Agreement very closely emulated the UNWC, listing almost identical procedural and substantive obligations. It could thus be read as general Egyptian and full Ethiopian support for the principles of the UNWC. ${ }^{12}$ 
Table 2. Summary of relevant clauses and use of international water law (IWL) by upstream states along the Jordan, Nile, and Tigris and Euphrates Rivers.

\begin{tabular}{|c|c|c|c|c|}
\hline $\begin{array}{l}\text { Upstream } \\
\text { state }\end{array}$ & $\begin{array}{l}\text { National unilateral } \\
\text { hydraulic } \\
\text { development } \\
\text { interests }\end{array}$ & Actual use of IWL & $\begin{array}{l}\text { IWL principles } \\
\text { invoked in support } \\
\text { of national interests } \\
\text { (ERU, NSH, PN) }\end{array}$ & $\begin{array}{c}\text { Possible basis of } \\
\text { argument in support } \\
\text { of unilateral national } \\
\text { interests }\end{array}$ \\
\hline \multicolumn{5}{|c|}{ Eastern Nile (downstream Egypt, hegemon) } \\
\hline Ethiopia & $\begin{array}{l}\text { Construction of the } \\
\text { Grand Ethiopian } \\
\text { Renaissance Dam } \\
\text { (started in 2011) }\end{array}$ & $\begin{array}{l}\text { Considerable - IWL served to } \\
\text { guide the CFA, which } \\
\text { Ethiopia has supported }\end{array}$ & ERU, NSH, PN & $\begin{array}{l}\text { Countermeasures, } \\
\text { foreclosure of } \\
\text { future use }\end{array}$ \\
\hline Sudan & $\begin{array}{l}\text { Irrigation, at least to } \\
\text { its } 18.5 \mathrm{~km}^{3} / \mathrm{y} \\
\text { share }\end{array}$ & $\begin{array}{l}\text { Considerable - IWL served to } \\
\text { guide the CFA, which Sudan } \\
\text { eventually rejected }\end{array}$ & ERU, NSH, PN & $\begin{array}{l}\text { Countermeasures, } \\
\text { foreclosure of } \\
\text { future use }\end{array}$ \\
\hline \multicolumn{5}{|c|}{ Jordan River and TB aquifers (downstream Israel, hegemon) } \\
\hline Lebanon & $\begin{array}{l}\text { Plans to develop the } \\
\text { Ebl el Saqi dam } \\
\text { (and to develop } \\
\text { groundwater) }\end{array}$ & $\begin{array}{l}\text { Medium - invoked during } 2002 \\
\text { Wazzani dispute }\end{array}$ & ERU only & $\begin{array}{l}\text { Countermeasures, } \\
\text { foreclosure of } \\
\text { future use }\end{array}$ \\
\hline Palestine & $\begin{array}{l}\text { Exploitation of } \\
\text { Western Aquifer } \\
\text { Basin }\end{array}$ & $\begin{array}{l}\text { Considerable - IWL forms } \\
\text { basis of negotiating position }\end{array}$ & ERU, NSH, PN & $\begin{array}{l}\text { Countermeasures, } \\
\text { foreclosure of } \\
\text { future use }\end{array}$ \\
\hline \multicolumn{5}{|c|}{ Tigris (upstream Turkey, hegemon) } \\
\hline Turkey & GAP project & $\begin{array}{l}\text { From opposition to minor use: } \\
\text { rejection of UNWC in 1997; } \\
\text { some use of ERU during } \\
\text { 1980s negotiations with } \\
\text { Syria }\end{array}$ & NSH, PN only & $\begin{array}{l}\text { Foreclosure of } \\
\quad \text { future use }\end{array}$ \\
\hline Iran & $\begin{array}{l}\text { Multiple projects on } \\
\text { the Tigris } \\
\text { tributaries }\end{array}$ & None apparent & NSH, PN only & $\begin{array}{l}\text { Foreclosure of } \\
\text { future use }\end{array}$ \\
\hline
\end{tabular}

Note. ERU = equitable and reasonable utilization; $\mathrm{NSH}=$ no significant harm; $\mathrm{PN}=$ prior notification; $\mathrm{CFA}=$ cooperative framework agreement; GAP indicates Southeastern Anatolia Project.

The government of Ethiopia's initiation of construction of the Grand Ethiopian Renaissance Dam in 2011 occurred outside of the Nile Basin Initiative (NBI) process, and contains no indication of being guided by IWL (IPoE, 2013); yet the Declaration of Principles (signed March 2015) has certainly taken on board the obligations of significant harm and equitable and reasonable use (if in different terms).

Countermeasures could be invoked by Ethiopia to breach the no significant harm principle following decades of Egyptian thwarting of upstream development (Brunnée \& Toope, 2002; Phillips \& Woodhouse, 2009; Waterbury, 2002), though this may not be politically expedient under current circumstances. Midstream between Ethiopia and Egypt, Sudanese support for IWL is more ambiguous (Eissa, 2008). The Sudanese government's refusal to sign the Cooperative Framework Agreement may have been based more on concern over re-allocation of Nile flows (see Mekonnen, 2010; Salman, 2013) than on direct opposition to IWL. Its participation in the $1959 \mathrm{Egypt}-$ Sudan treaty still assures the state the right to "develop" an additional 1-5 $\mathrm{km}^{3} / \mathrm{y}$ (Mohieldeen, 2008), much of which is likely to be made possible following the Ethiopian construction of the Grand Ethiopian Renaissance Dam further upstream. In this sense, the UNWC and the UNECE Water Convention (and IWL more generally) appear to support the development interests of both upstream countries. 


\section{Jordan River and transboundary aquifers}

The obstacles to hydraulic development by Lebanon and Palestine - upstream of Israel on the Jordan River and transboundary aquifers, respectively - have been well documented (Amery, 2002; Selby, 2013; World Bank, 2009; Zeitoun, Eid-Sabbagh, Dajani, \& Talhami,

2012). ${ }^{13}$ Lebanon's ratification of the UNWC may have originally been swayed by Syrian influence over the country (AFIAL, 2014), but the principle of equitable and reasonable use was invoked clearly by the Lebanese government during the 2002 Wazzani Springs dispute (GOL, 2002), concerns expressed by Israel about its selective use of IWL (i.e. no mention of no significant harm) notwithstanding (Zeitoun, Talhami, \& Eid-Sabbagh, 2013). The UNWC - and in particular the principle of equitable and reasonable use has also served as the foundation for the Palestinian proposal for resolution of the Palestinian-Israeli water conflict, in its formal negotiations with Israel (Phillips, Attili, McCaffrey, \& Murray, 2005; PWA, 2012; RPSO, 2009).

Given the asymmetry in control by the downstream hegemon in both cases, countermeasures could be argued as the basis for a breach by either Lebanon or Palestine of any of its obligations, in light of significant downstream development (foreclosure). In the current balance of power, however, such an argument would not be expected to be developed, any more than the Lebanese plans for the Ebl el Saqi Dam on the Hasbani River (RoL, 2008) or Palestinian aspirations for deep wells in the Western Aquifer Basin (Koek, 2013; MacDonald et al., 2009). Lebanon has also commented on the Draft Aquifer Articles - regarding clarification of the terms 'aquifer' and 'aquifer state' (UNGA, 2012, comment 39) - but has not commented on the introduction of the term 'sovereignty'. In contrast, the official comment by Israel at the Draft Aquifer Articles' first reading (in the Commission's 60th Session, May/June 2008) clearly supports the introduction of the concept of sovereignty to the draft legal articles (see also Eckstein \& Sindico, 2014). ${ }^{14}$

\section{Tigris River}

It is along the Tigris River that the distinction between riparian position, power and law becomes most clear. In contrast to the other cases, no downstream hegemon has (recently) impeded the hydraulic development of upstream riparians on the Tigris, to say the least. Both Turkey and Iran are wholly engaged in 'hydraulic missions', the negative impacts of which are felt first and foremost in downstream Iraq (see e.g. Chavoshian, Takeuchi, \& Funada, 2005; Masih, 2011; UN-ESCWA/BGR, 2013, chs 3, 5; Zawahri \& Gerlak, 2009). ${ }^{15}$ Neither state is turning to IWL to support its activities in the basin, and there are no treaties that claim to shape water sharing within it. For instance, the 2009 Turkish policy clearly prioritizes "sovereign right" over the principles of "no significant harm" and "equitable, reasonable, and optimum" use (Kramer \& Kibaroglu, 2011, p. 217). Turkish opposition to the UNWC has been consistent in public and closed-door meetings. The Turkish government was one of only three to vote against the UWNC in 1997, has argued against it at the UN General Assembly on the grounds that it does not recognize a state's sovereign rights (UNGA, 1997), and has, moreover, suggested deletion of the no significant harm rule (Kibaroglu, 2015). There is nuance, of course - the fact that 'no harm' and 'equitable and reasonable use' are mentioned at all in the national policy suggests Turkish use of IWL, at least as a rhetorical device to improve its bargaining position (Daoudy, 2007). Turkey also supported the introduction of 'sovereignty' to the Draft Aquifer Articles at its first reading. ${ }^{16}$ 
The government of Iran originally supported the UNWC, but has not followed with ratification, nor commented on the Draft Aquifer Articles. Currently facing significant internally created water crises (Gohari et al., 2013; Madani, 2014), the government of Iran is not expected to risk delaying development efforts by opening negotiations on downstream impacts (Al-Faraj \& Scholz, 2015, Nageeby, 2014) - despite its own downtream position in relation to Afghanistan (Thomas and Warner, 2015). Although Iraq has acceded to the UNWC, previous governments have not promoted any allocation of flows based on equitable and reasonable use (Çonker, 2014; Trondalen, 2008). The government of Iraq thus finds itself in the hydropolitical position that the government of Egypt may well find itself in: as a downstream early developer that did not employ IWL as a guide to fair water sharing when it had the opportunity to do so, and so is vulnerable to upstream development.

As with the other cases, there is nothing in the letter or interpretation of IWL that obstructs Iran or Turkey from completing their upstream development plans. Both states could highlight the extensive Iraqi development during the 1950s-1990s, invoking foreclosure of future uses as the basis of their argument. This would have to be tempered with the primacy of the principle of equitable and reasonable use, however, suggesting greater consideration to downstream impacts be given.

Concluding discussion: the relevance of IWL to late-developing upstream states

The analysis of legal theory and cases has made a number of points of note to this article's goal of investigating the extent to which IWL is relevant to later-developing upstream states. Contrary to the perceptions of perhaps many in the non-legal water community, there are no terms in any of the instruments of IWL that might be interpreted to inhibit their hydraulic development plans. The UNECE Water Convention, UN Watercourses Convention, and Draft Aquifer Articles are each evaluated as a coherent instrument to determine an upstream state's entitlement to use watercourses within its legal obligations to other states (to return to the role claimed by IWL). Research arguing that IWL is biased towards first-developing downstream states (e.g. Wegerich \& Olsson, 2010) may result from a tendency to downplay the role that foreclosure, reciprocity, and countermeasures can play in developing a case in support of upstream hydraulic development (see also Brooks, 2011). But the argument also reflects an awareness of the politics of law that ensures a sharp distinction between the letter and spirit of IWL, and its application. It is from within this gap between theory and reality that the limits of IWL - for any state - are revealed.

Indeed, the analysis has shown that IWL's ability to influence actual transboundary water arrangements must be qualified. IWL continues to guide the behaviour of states on the Eastern Nile through the 2010 Cooperative Framework Agreement and the 2015 Declaration of Principles. While this is seen as an outcome of the recent shifts in power asymmetry between the states, IWL is nonetheless serving a somewhat coordinated effort to share the common resource. Along the Jordan, despite guiding the positions of the weaker upstream states, the lack of change in water sharing over several decades is more accurately attributed to the pursuit of unilateral state interests, buttressed by power asymmetry. IWL has been used instrumentally by the more powerful states along the Tigris, leaving downstream Iraq at the mercy of upstream states that either ignore IWL or officially prioritize sovereign rights over collective ones.

Furthermore, the ability of IWL to influence state behaviour is found to be threatened, both in theory and practice, because of the inherent tensions created by sovereign political 
entities seeking to govern a resource that spans their borders. One threat to the relevance of IWL stems from its discrediting. Though the UNWC has entered into force, a majority of states - basin hegemons, typically - do not support the it, and some actively oppose it (Adelphi, 2014; DFID, 2008; WWF-DFID, 2010). If the relevance of international law comes through norm building and in other 'soft' ways, as asserted here, then the political and legal advances made to govern fluid transboundary resources across static territorial borders may yet be reversed. A second, related, threat is to the robustness of the body of IWL, which has been found to be challenged by potential incompatibility between the various instruments, notably the sovereignty clause introduced by the Draft Aquifer Articles. The analysis has exposed how this incompatibility may reduce the effectiveness (or reputation of effectiveness) of IWL - and thus perpetuate ideas about its nonrelevance.

Analysis of empirical findings and literature indicates that these threats are tied to a third, even greater threat: the apparent shift of IWL away from the guiding doctrine of limited territorial sovereignty and towards absolute territorial sovereignty. In the sense that the shift indicates a greater engagement with IWL by states that have otherwise denigrated it or use it instrumentally (Turkey and Israel, in the cases considered here), it counters the first of the threats mentioned above. Indeed, the evolution towards absolute territorial sovereignty makes IWL not simply relevant to upstream states; it may actually mean that IWL favours them. This is because they already enjoy political sovereignty over the territory where a transboundary watercourse arises or recharges - and may now extend that territorial sovereignty, with some argument, to the water that flows through the aquifer.

This type of relevance merits scrutiny for its potential long-term effects. With an appreciation that relative power asymmetry is more determining of control over a transboundary resource than is riparian position (Zeitoun \& Warner, 2006), the assertion that the introduction of the sovereignty clause may favour upstream states more accurately holds for the more powerful states, whether up-, mid-, or downstream. This is because of the way that states may use the various forms of power at their disposal to employ international law in general to meet their unilateral interests, usually with impunity (Hathaway, 2005; Koh, 1997). Whether these more powerful states choose to achieve multilateral interests (and thereby conform e.g. to IWL) is related to the extent that the reinforcement of international norms also meets their unilateral interests - and these are typically shaped by political and economic forces. Thus, even with the drift towards absolute territorial sovereignty, IWL may serve for coordinated development where relations between the states are good.

In the worst of cases, IWL risks serving uncoordinated development of transboundary watercourses, in the same way that the political economy does (see e.g. Conca, 2006; Earle, Jägerskog, \& Öjendal, 2010). In this sense, recommendations to harmonize the legal instruments appear the best legal route forward (McCaffrey, 2011; McIntyre, 2011). The non-legal water community has a role to play here, too, however - at least in support of the norm-building processes that re-affirm the doctrine of limited territorial sovereignty and which ensure that the principles of IWL are pursued in practice, even if they are not in theory.

The research has exposed more questions that should be answered. It would be beneficial to understand, for instance, the conditions under which some upstream states invoke equitable and reasonable use (Lebanon and Ethiopia, in our cases) and some do not (Turkey or Sudan - see Salman, 2014). Further research is also required to move beyond the limits imposed by the specifics of this article. Testing the methods 
developed here on hydropolitical constellations with entirely different sets of relations and patterns of river flow or aquifer recharge would be one step in this direction; more evidence of the influence of politics over the creation and application of IWL would be another.

\section{Acknowledgements}

Thanks are due to Stephen McCaffrey (for general guidance and specific input on 'countermeasures'), Ghadir el Aleyli, Ziad Baroud, Alistair Rieu-Clarke, and Michael Talhami.

\section{Funding}

This work was supported by the Ibrahim Abd el Al Foundation.

\section{Notes}

1. Subject to ratifications of the amendment, including by Ukraine.

2. These other bodies of law are not discussed further here, due to limited space. Note the crossinstrument work by Leb (2012), Tignino (2011a, 2011a), and Miroso \& Harris (2012).

3. The evolution of IWL has been well covered in many texts, including Salman (2007), RieuClarke et al. (2012), Leb (2013), and Gander (2014). It is therefore covered only selectively here.

4. The remaining two doctrines are variants of the two discussed. The doctrine of absolute territorial integrity "imposes a duty on [upstream] state[s] not to restrict such natural flow of waters to other lower riparians" (Salman, 2007, p. 627). At a superficial level, absolute territorial integrity seems clearly in the interests of downstream states, and has been largely discredited for the impact it can have on upstream states (i.e. preventing or compromising any development of the river by the upstream state). Like limited territorial sovereignty, the doctrine of 'community of interests' rises above the notion of sovereignty by considering how the flow of water renders it more compatible with being viewed as common property and in the common interests of the states the water runs through (McCaffrey, 2007). The selection of principles reviewed here is based on the author's judgement of those most relevant to the specific focus of the article.

5. The main actors in the development of international water law include two scholarly NGOs, the Institute of International Law (IIL) and the International Law Association (ILA); and two UN bodies, the International Law Commission (ILC) and the UN Economic Commission for Europe (UNECE).

6. Conceptual work on the coordinated implementation of the two conventions is underway (see e.g. Kinna, Rieu-Clarke, and Rocha Loures, 2013; UNECE, 2013).

7. At its autumn 2013 session, the General Assembly decided to delay the vote a second time, by including the item in the agenda of its 71st (2016) session.

8. This recognition is evident first and foremost in World Bank practice.

9. The court recognized there the right of an injured state to take "certain measures, including countermeasures", in the case of "violation of . . . treaty rules or of rules of general international law".

10. The selection of rules checked is limited to those considered by the author to be of the most relevance to the purpose of the article. The compatibility of a greater number of rules is checked in Afial (2014). The compatibility of the UNWC and the UNECE Water Convention has been confirmed by McCaffrey (2014) and Rieu-Clarke and Kinna (2014), who recommend that states accede to and employ both instruments.

11. A related principle details obligations relevant to the prevention and control of transboundary water pollution. The obligation to "prevent, reduce, and control" pollution is strongly asserted in much the same wording in the UNWC (Art. 21), the Draft Aquifer Articles (Art. 11) and the UNECE Water Convention (Art. 2.2).

12. Sudan sponsored the UNWC in 1997; both Ethiopia and Egypt abstained. Ethiopia, Sudan and Egypt have not commented on the Draft Aquifer Articles. 
13. With Palestine's ratification of the UNWC in January 2015 (to enter into force 2 April 2015), both upstream entities on the Jordan River (as well as Jordan and Syria) have ratified the UNWC.

14. "Israel welcomes the emphasis the draft articles give to the issue of sovereignty over transboundary aquifers" (UN ILC, 2008, comment 92). The position is then qualified: "However, Israel does not support the making of exceptions to accepted international law on this issue. Therefore, Israel suggests adding the words 'international law and' after the word 'with' to draft article 3."

15. Turkey is downstream of Lebanon and upstream of Greece on other rivers. The general policy of the government of Turkey on IWL cannot be gauged from examination of the Tigris and Euphrates alone (Çonker, 2014). Likewise, to understand Iran's position on water law and transboundary water policy one must consider its many other transboundary rivers and aquifers, particularly when it is downstream (Hanasz, 2012; Nageeby, 2014).

16. "An explicit reference to the sovereignty of States over the natural resources within their territories is preferred. This reference is particularly important in case that dialogue or cooperation among the riparian States of the transboundary aquifer is not at the level which enables joint equitable and reasonable utilization" (UN ILC, 2008, comment 94 [Turkey]). The comment then suggests wording that makes the importance of "sovereignty" even more explicit than in the final version.

\section{References}

Adelphi. (2014). The rise of hydro-diplomacy: Strengthening foreign policy for transboundary waters. Climate Diplomacy Report. Berlin: Adelphi, with the German Federal Foreign Office.

AFIAL. (2014). Legal analysis of transboundary waters in the Upper Jordan River Basin. Beirut: Association of the Friends of Ibrahim Abd el Al.

Al-Faraj, F. A. M., \& Scholz, M. (2015). Impact of upstream anthropogenic river regulation on downstream water availability in transboundary river watersheds. International Journal of Water Resources Development, 31(1), 28-49. doi:10.1080/07900627.2014.924395

Allan, J. A. (2001). The Middle East water question: Hydropolitics and the global economy. London, UK: I.B. Tauris.

Amery, H. A. (2002). Water wars in the Middle East: A looming threat. The Geographical Journal, 168(4), 313-323. doi:10.1111/j.0016-7398.2002.00058.x

Beaumont, P. (2005). Water institutions in the Middle East. In C. Gopalakrishnan, C. Tortajada, \& A. Biswas (Eds.), Water institutions: Policies, performance, and prospects. New York, NY: Springer.

Brooks, D. B. (2011). Response to Late developers and the inequity of "equitable utilization" and the harm of "do no harm" by Kai Wegerich and Oliver Olsson, Water International, 35 (6), 707-717 (November 2010). WaterInternational, 36(3), 407-409. doi:10.1080/02508060.2011.581867

Brunnée, J., \& Toope, S. J. (2002). The changing Nile Basin Regime: Does law matter? Harvard International Law Journal, 43(1), 105-159.

Cascão, A. E. (2014, May 12/13). Countering hydro-hegemony in the Nile Basin. Presentation given at Seventh International Workshop on Hydro-Hegemony, London UEA Water Security Research Centre/London Water Research Group.

Chavoshian, S. A., Takeuchi, K., \& Funada, S. (2005). An overview to transboundary and shared water resources management in Iran, technical challenges and solutions. Role of Water Sciences in Transboundary River Basin Management, Thailand.

Conca, K. (2006). Governing water: Contentious transnational politics and global institution building. Cambridge, MA: Massachusetts Institute of Technology Press.

Çonker, A. (2014). An enhanced notion of power for inter-state and transnational hydropolitics: An analysis of Turkish-Syrian Water Relations and the Ilisu Dam $(\mathrm{PhD}$ thesis submitted to the School of International Development). University of East Anglia.

Cronin, R., \& Hamlin, T. (2010). Mekong tipping point. Washington, DC: Henry L. Stimson Center. Cullet, P. (2011). Water law in a globalised world: The need for a new conceptual framework. Journal of Environmental Law, 23(2), 233-254. doi:10.1093/jel/eqr003

D'Souza, R. (2010). Law and 'Development' discourses about water: Understanding agency in regime changes. In P. Cullet, A. Gowlland-Gualtieri, R. Madhave, \& U. Ramanathan (Eds.), 
Water governance in motion: Towards socially and environmentally sustainable water laws. Bangalore: Cambridge University Press India.

Daoudy, M. (2007). Conceptualizing and disentangling cooperation. Presentation given at the Third International Workshop on Hydro-Hegemony, 12 and 13 May 2007, London School of Economics, London, UK, London Water Research Group.

Daoudy, M. (2008). Hydro-hegemony and international water law: Laying claims to water rights. Water Policy, 10(S2), 89-102. doi:10.2166/wp.2008.204

Del Castillo-Laborde, L. (2011). The Law of Transboundary Aquifers: Scope and rippling effects. In J. Ganoulis, A. Aureli, \& J. Fried (Eds.), Transboundary water resources management: A multidisciplinary approach. Weinheim: Wiley-VCH Verlag GmbH \& Co.

Dellapenna, J.W.(2001). The customary international law of transboundary fresh waters. International Journal of Global Environmental Issues, 1(3/4), 264-305. doi:10.1504/IJGENVI.2001.000981

Dellapenna, J. W. (2003). Water rights and international law. In E. Nicholson and P. Clark (Eds.), The Iraqi marshlands: A human and environmental study. London: Politico's.

Delli-Priscoli, J., \& Wolf, A. (2008). Managing and transforming water conflicts. Cambridge: Cambridge University Press.

DFID. (2008). Open letter on accession to the UN convention on the law of non-navigational uses of international watercourses. Letter by UK Department for International Development of 28 April 2008 , in response to a letter signed by over tweny UK-based academics.

Dinar, A., Katz, D., De Stefano, L., \& Blankspoor, B. (2012, October 18-19). Climate change, conflict, and cooperation: Global analysis of the resilience of international river treaties to increased water variability. Rethinking Climate Change, Conflict, and Security Conference, Unversity of Sussex.

DNI. (2012). Global water security - Intelligence community assessment. ICC-coordinated paper. Washington, DC. Office of the Director of National Intelligence, US Department of State.

Earle, A., Jägerskog, A., \& Öjendal, J. (2010). Transboundary water management: Policy and practice. London: Routledge.

Eckersley, R. (2004). The green state: Rethinking democracy and sovereignty. Cambridge, MA: The MIT Press.

Eckstein, G., \& Sindico, F. (2014). The Law of Transboundary Aquifers: Many ways of going forward, but only one way of standing still. Review of European, Comparative \& International Environmental Law, 23(1), 32-42. doi:10.1111/reel.12067

Eckstein, G. E. (2011). Managing buried treasure across frontiers: The international Law of Transboundary Aquifers. Water International, 36(5), 573-583. doi:10.1080/ 02508060.2011 .598642

Fox, C. A., \& Sneddon, C. (2007). Transboundary river basin agreements in the Mekong and Zambezi basins: Enhancing environmental security or securitizing the environment? International Environmental Agreements: Politics, Law and Economics, 7(3), 237-261. doi:10.1007/s10784007-9036-4

Gander, M. J. (2014). International water law and supporting water management principles in the development of a model transboundary agreement between riparians in international river basins. Water International, 39(3), 315-332. doi:10.1080/02508060.2013.880006

Gleditsch, N. P., Furlong, K., Hegre, H., Lacina, B., \& Owen, T. (2006). Conflicts over shared rivers: Resource scarcity or fuzzy boundaries? Political Geography, 25, 361-382. doi:10.1016/j. polgeo.2006.02.004

Gohari, A., Eslamian, S., Mirchi, A., Abedi-Koupaei, J., Bavani, A. M., \& Madani, K. (2013). Water transfer as a solution to water shortage: A fix that can Backfire. Journal of Hydrology, 491, 2339. doi:10.1016/j.jhydrol.2013.03.021

GOL. (2002). Position report: Service area of Hasbani watercourse. Final Copy 09 October 2002, with 'Rapport de synthese' and 'Plan de developpement pour le bassin versant du HasbaniWazzani', in annex. Beirut, Government of Lebanon.

Goldsmith, J. L., \& Posner, E. A. (2005). The limits of international law. Oxford: Oxford University Press.

Hanasz, P. (2012). The politics of water security between Afghanistan and Iran. Strategic Analysis Paper. Perth: Future Directions International.

Hathaway, O. A. (2005). Between power and principle: An integrated theory of international law. Faculty Scholarship Series Paper 836 Yale Law School Legal Scholarship Repository. 
Hensengerth, O., Dombrowski, I., \& Scheumann, W. (2012). Benefit-Sharin in dam projecs on shared riverss (Discussion Paper 6/2012). Bonn: Deutsches Institut für Entwicklungspolitik/ German Development Institute.

IPoE. (2013). Grand Ethiopian Renaissance dam project - Final report. Addis Ababa: Independent Panel of Experts.

Kibaroglu, A. (2015). An analysis of Turkey's water diplomacy and its evolving position vis-à-vis international water law. Water International, 40(1), 153-167. doi:10.1080/ 02508060.2014 .978971

Kinna, R., Rieu-Clarke, A. and Rocha Loures, F. (2013). Global UN water conventions: Options for coordinated implementation. Discussion Paper. University of Dundee.

Koek, E. (2013). Water for one people only: Discriminatory access and 'water-apartheid' in the OPT. Ramallah: Al-Haq.

Koh, H. H. (1997). Why do nations obey international law? Faculty Scholarship Series Paper 2101 Yale Law School Legal Scholarship Repository.

Kramer, A., \& Kibaroglu, A. (2011). Turkey's position towards International Water Law. In A. Kibaroglu, W. Scheumann, \& A. Kramer (Eds.), Turkey's water policy: National frameworks and international cooperation. Heidelberg: Springer-Verlag.

Lankford, B. (2013). Does article 6 (factors relevant to equitable and reasonable utilization) in the UN Watercourses Convention misdirect riparian countries? Water International, 38(2), 130145. doi:10.1080/02508060.2013.780687

Leb, C. (2012). The right to water in a transboundary context: Emergence of seminal trends. Water International, 37(6), 640-653. doi:10.1080/02508060.2012.710950

Leb, C. (2013). The UN Watercourses Convention: The éminence grisebehind cooperation on transboundary water resources. Water International, 38(2), 146-155. doi:10.1080/02508060.2013.781474

Leb, C. (2015). One step at a time: International law and the duty to cooperate in the management of shared water resources. Water International, 40(1), 21-32. doi:10.1080/02508060.2014.978972

Litfin, K. T. (1997). Sovereignty in world ecopolitics. Mershon International Studies Review, 41, 167-204. doi: $10.2307 / 222667$

MacDonald, A. M., Dochartaigh, B. É. Ó., Calow, R. C., Shalabi, Y., Selah, K., \& Merrett, S. (2009). Mapping groundwater development costs for the transboundary Western Aquifer Basin, Palestin/Israel. Hydrogeology Journal, 17, 1579-1587. doi:10.1007/s10040-009-0471-x

Madani, K. (2014). Water management in Iran: What is causing the looming crisis? Journal of Environmental Studies and Sciences, 4, 315-328. doi:10.1007/s13412-014-0182-z

Magsig, B.-O. (2015). International Water Law and the quest for common security. Oxon: Routledge.

Masih, I. (2011). Understanding hydrological variability for improved water management in the Semi-Arid Karkeh Basin, Iran (PhD Dissertation). Delft University of Technology.

McCaffrey, S. (2007). The law of international watercourses. Oxford: Oxford University Press.

McCaffrey, S. (2008). The 1997 UN Watercourses Convention: Retrospect and prospect. 21 Pac. McGeorge Global Bus. \& Dev. L.J. 165.

McCaffrey, S. C. (2011). The International Law Commission's flawed draft articles on the Law of Transboundary Aquifers: The way forward. Water International, 36(5), 566-572. doi:10.1080/ 02508060.2011 .597094

McCaffrey, S. (2013). The codification of universal norms: A means to promote cooperation and equity? In L. Boisson de Chazournes, C. Leb, \& M. Tignino (Eds.), International law and freshwater: The multiple challenges (pp. 125-154). Cheltenham: Edward Elgar.

McCaffrey, S. C. (2014). International water cooperation in the 21st century: Recent developments in the law of international watercourses. Review of European, Comparative \& International Environmental Law, 23(1), 4-14. doi:10.1111/reel.12064

McIntyre, O. (2007). Environmental protection of international watercourses under international law. Hampshire: Ashgate.

McIntyre, O. (2011). International water resources law and the international law commission draft articles on transboundary aquifers: A missed opportunity for cross-fertilisation? International Community Law Review, 13, 1-18. doi:10.1111/j.1467-9388.2004.00379.x

McIntyre, O. (2015). Benefit-sharing and upstream/downstream cooperation for ecological protection of transboundary waters: Opportunities for China as an upstream state. Water International, 40(1), 48-70. doi:10.1080/02508060.2014.990350 
Mekonnen, D. Z. (2010). The Nile basin cooperative framework agreement negotiations and the adoption of a 'water security' paradigm: Flight into obscurity or a logical Cul-de-sac? European Journal of International Law, 21, 421-440. doi:10.1093/ejil/chq027

Miroso, O., \& Harris, L. M. (2012). Human right to water: Contemporary challenges and contours of a global debate. Antipode, 44(3), 932-949.

Mohieldeen, Y. (2008). Sudan's Nile waters and the eastern Nile basin: Hydropolitics in a politicized environment. PhD thesis. Department of Geography, School of Oriental and African Studies, London.

Molle, F., Mollinga, P. P., \& Wester, P. (2009). Hydraulic bureaucracies and the hydraulic mission: Flows of water, flows of power. Water Alternatives, 2(3), 328-349.

Moussa, J. (2013, March 8). International Water Law \& allocation in the Nile Basin: A coherent system of law or empty rhetoric? Presentation given to the UEA Water Security Research Centre, University of East Anglia, Norwich, UK.

Nageeby, M. (2014). Analysis of the hydro-political impacts of dam development in transboundary river basins: A case study of the Harirud River Basin (MSc Thesis No. WM-WCM). UNESCOIHE Institute for Water Education, Delft.

Nicol, A., \& Cascão, A. E. (2011). Against the flow - New power dynamics and upstream mobilisation in the Nile Basin. Review of African Political Economy, 38(128), 317-325. doi:10.1080/03056244.2011.582767

Olmstead, S. M., \& Sigman, H. (2014). Damming the commons: An empirical analysis of international cooperation and conflict in dam location (Discussion Paper $14-23$ ). Washington, DC. Resources for the Future, 1-35.

Phillips, D., Attili, S., McCaffrey, S., \& Murray, J. (2005, May 21/22). Water and the Jordan River co-riparians: From a zero-sum to a positive-sum game. Presentation given at the First Workshop on Hydro-Hegemony, London Water Research Group, London, UK.

Phillips, D., \& Woodhouse, M. (2009). Benefit sharing in the Nile River Basin: Strategies for fresh water use at the country and sub-basin levels. Entebbe: Report prepared for the Socio-economic Development and Benefit Sharing Unit of the Nile Basin Initiative.

PWA. (2012). The positive-sum outcome: A solution for all (brochure). Ramallah: Palestinian Water Authority.

Rieu-Clarke, A. (2010). The role of treaties in building international watercourse regimes: A legal perspective on existing knowledge. Water Policy, 12(6), 822-831. doi:10.2166/wp.2010.039

Rieu-Clarke, A., \& Kinna, R. (2014). Can two global UN Water Conventions effectively co-exist? Making the case for a 'Package Approach' to support institutional coordination. Review of European, Comparative \& International Environmental Law, 23(1), 15-31. doi:10.1111/ reel. 12070

Rieu-Clarke, A., Moynihan, R., \& Magsig, B.-O. (2012). UN watercourses convention: User's guide. Dundee: IHP-HELP Centre for Water Law, University of Dundee.

RoL. (2008). Ebl El Saqi proposed dam: Final report master plan. Beirut: Ministry of Energy and Water, General Directorate of Hydraulic and Electrical Resources (Republic of Lebanon). With Rafik El-Khoury \& Partners.

RPSO. (2009). Trans-boundary cooperation on the Jordan River Basin: A regional positive-sum outcome Pamphlet not attributed to any source.

Saleh, S. M. K. (2008). International law and hydro-hegemony in the Nile Basin: A Sudanese perspective. Water Policy, 10(S2), 29-49. doi:10.2166/wp.2008.205

Salman, S. M. A. (2007). The Helsinki rules, the UN Watercourses Convention and the Berlin rules: Perspectives on International Water Law. International Journal of Water Resources Development, 23(4), 625-640. doi:10.1080/07900620701488562

Salman, S. M. A. (2010). Downstream riparians can also harm upstream riparians: The concept of foreclosure of future uses. Water International, 35(4), 350-364. doi:10.1080/02508060.2010.508160

Salman, S. M. A. (2013). The Nile Basin cooperative framework agreement: A peacefully unfolding African spring? Water International, 38(1), 17-29. doi:10.1080/02508060.2013.744273

Salman, S. M. A. (2014). Entry into force of the UN Watercourses Convention - Where are the Nile Basin countries? International Water Law Project Blog. Retrieved from http://www.internatio nalwaterlaw.org/blog/2014/06/02/

Selby, J. (2013). Cooperation, domination and colonisation: The Israeli-Palestinian joint water committee. Water Alternatives, 6(1), 1-24. 
Stephens, T. (2012). Reimagining International Water Law. DigitalCommons@UM Carey Law University of Maryland Francis King Carey School of Law, 20-40.

Stimson. (2010). Fresh water futures: Imagining responses to demand growth, climate change, and the politics of Water Resource Management by 2040. Washington, DC: The Stimson Center.

Swyngedouw, E. (1999). Modernity and hybridity: Nature, regeneracionismo, and the production of the Spanish Waterscape, 1890-1930. Annals of the Association of American Geographers, 89 (3), 443-465. doi:10.1111/0004-5608.00157

Tanzi, A. (2013). Regional contributions to international water cooperation: The UNECE contribution. In L. Boisson de Chazournes, C. Leb, \& M. Tignino (Eds.), International law and freshwater: The multiple challenges (pp. 155-178). Cheltenham: Edward Elgar.

Thomas, V. and Warner, J. (2015). Hydropolitics in the Harirud/Tejen River Basin: Afghanistan as hydro-hegemon? Water International, 40(4), 593-613. http://dx.doi.org/10.1080/02508060. 2015.1059164

Tignino, M. (2011a). The right to water and sanitation in post-conflict peacebuilding. Water International, 36(2), 242-249. doi:10.1080/02508060.2011.561523

Tignino, M. (2011b). L'eau et la guerre - Eléments pour un régime juridique. Geneva: Faculty of Law. University of Geneva.

Trondalen, J. M. (2008). Water and peace for the people: Possible solutions to water disputes in the Middle East. Paris: UNESCO Publishing.

UN. (2012). Materials on the responsibility of states for internationally wrongful acts. New York, NY: United Nations Legislative Series ST/LEG/SER.B/25.

UN ILC. (2008). Shared natural resources: Comments and observations by Governments on the draft articles on the Law of Transboundary Aquifers. Refers to Report of the International Law Commission, Sixtieth session. Ref A/CN.4/595 International Law Commission.

UN-ESCWA/BGR. (2013). Inventory of shared water resources in Western Asia. Beirut: UN Economic and Social Commission for Western Asia (ESCWA), and the German Federal Institute for Geosciences and Natural Resources (BGR).

UNECE (1992). Convention on the protection and use of transboundary watercourses and international lakes. Helsinki, 17 March 1992. UN Economic Commission for Europe.

UNECE. (2011). Second assessment of transboundary rivers, lakes and groundwaters. ECE/MP. WAT/33. United Nations Economic Commission for Europe.

UNECE (2013). Guide to implementing the Water Convention. ECE/MP.WAT/39. United Nations Economic Commission for Europe - Convention on the protection and use of transboundary watercourses and international lakes.

UNGA. (1997, May 21). General assemply adopts convention on law of non-navigational uses of international watercourses. New York, NY: UNGA/9248.

UNGA. (2012). Sixth Committee - Summary record of the 16th meeting held at headquarters 18 October 2011. Ref A/C.6/66/SR.16 UN General Assembly.

Vink, K. (2014). Transboundary water law and vulnerable people: Legal interpretations of the 'equitable use' principle. Water International, 39(5), 743-754. doi:10.1080/ 02508060.2014 .951827

Waterbury, J. (2002). The Nile: national determinants of collective action. Ann Arbor, MI: Yale University Press.

Wegerich, K., \& Olsson, O. (2010). Late developers and the inequity of "equitable utilization" and the harm of "do no harm". Water International, 35(6), 707-717. doi:10.1080/02508060.2010.533345

World Bank. (2009). West Bank and Gaza: Assessment of Restrictions on Palestinian Water Sector Development Sector Note April 2009 (Report No. 47657-GZ). Middle East and North Africa Region - Sustainable Development. Washington, DC: The International Bank for Reconstruction and Development.

Wouters, P. (2014). The Yin and Yang of International Water Law: China's transboundary water practice and the changing contours of state sovereignty. Review of European, Comparative \& International Environmental Law, 23(1), 67-75. doi:10.1111/reel.12069

Wouters, P., \& Chen, H. (2015). Editors' introduction. Water International, 40(1), 1-20. doi: $10.1080 / 02508060.2014 .990144$

Wouters, P., Vinogradov, S., Allan, A., Jones, P., \& Rieu-Clarke, A. (2005). Sharing transboundary waters - An integrated assessment of equitable entitlement: The legal assessment model. International Hydrological Programme - Technical Documents in Hydrology No. 74. Paris: UNESCO. Especially Part 1, for theory. 
WWF-DFID. (2010). International architecture for transboundary water resources management: Policy analysis and recommendations. London: Worldwide Fund for Nature and the UK Department for International Development, with Pegasys Strategy and Development, and the UNESCO Centre for Water Law, Policy and Science.

Zawahri, N. A. (2008). International rivers and national security: The Euphrates, GangesBrahmaputra, Indus, Tigris and Yarmouk rivers. Natural Resources Forum, 32, 280-289. doi:10.1111/j.1477-8947.2008.00204.x

Zawahri, N. A., \& Gerlak, A. K. (2009). Navigating international river disputes to avert conflict. International Negotiation, 14, 211-227. doi:10.1163/157180609X432806

Zeitoun, M., Cascão, A., Warner, J., Mirumachi, N., Matthews, N., Farnum, R., \& Menga, F. (forthcoming). Transboundary water interaction III: Contesting hegemonic arrangements. International Environmental Agreements.

Zeitoun, M., Eid-Sabbagh, K., Dajani, M., \& Talhami, M. (2012). Hydro-political baseline of the Upper Jordan River. Beirut: Association of the Friends of Ibrahim Abd el Al.

Zeitoun, M., Mirumachi, N., \& Warner, J. (2011). Transboundary water interaction II: The influence of 'soft' power. International Environmental Agreements: Politics, Law and Economics, 11(2), 159-178. doi:10.1007/s10784-010-9134-6

Zeitoun, M., Talhami, M., \& Eid-Sabbagh, K. (2013). The influence of narratives on negotiations over and resolution of the Upper Jordan River Conflict. International Negotiation, 18(2), 293322. doi:10.1163/15718069-12341257

Zeitoun, M., \& Warner, J. (2006). Hydro-hegemony - A framework for analysis of trans-boundary water conflicts. Water Policy, 8(5), 435-460. doi:10.2166/wp.2006.054 